\title{
Session 6: Advances in Enzyme Science and Technology
}

\author{
Gisella Zanin • Kevin Gray
}

Published online: 25 March 2009

(C) Humana Press 2009

As ethanol from lignocellulosic materials progresses to commercial fruition, finer details of the hydrolysis process are being investigated. In this session, papers were presented that dealt with several aspects of biomass conversion including substrate effects, additives to the saccharification reaction, and high performance enzymes. The influence of each one of these aspects on hydrolysis performance was analyzed by different authors.

Rajeev Kumar from Dartmouth College described how the choice of pretreatment technology influences cellulose accessibility. He investigated how cellulose accessibility in poplar solids changed depending on the pretreatment method. The pretreatment methods used were ammonia fiber expansion (AFEX), ammonia recycle percolation (ARP), controlled $\mathrm{pH}$, dilute acid, lime, and sulfur dioxide. The main conclusion was that cellulase enzyme site accessibility is influenced by the type of pretreatment as well as by the type and composition of the substrate.

Maobing Tu from the Pulp and Paper Research Institute of Canada investigated the influence of added surfactant (Tween 80) on cellulose conversion of steam-exploded lodgepole pine and ethanol-pretreated lodgepole pine. He showed that the presence of Tween 80 resulted in a significant increase in the cellulose-to-glucose yield for the steamexploded substrate, but had no effect for the ethanol-treated substrate. In addition, the presence of surfactant increased the amount of free enzyme for both substrates implying that surfactant might be minimizing non-productive binding of cellulases to the surface. Lastly, the presence of surfactant did not affect final ethanol yields in SSF reactions with yeast.

Feng $\mathrm{Xu}$ from Novozymes observed that cellulose oxidation had a profound impact on the rate and extent of cellulose hydrolysis by single enzymes (cellobiohydrolases) and complete cellulase mixtures (Trichoderma reesei-secreted proteins). Thermochemical pretreatments may negatively affect enzymatic hydrolysis by producing inhibitory

G. Zanin $(\bowtie)$

University Estadual Maringa, Maringa, Brazil

e-mail: gisella@deq.uem.br

K. Gray

Verenium Corp., San Diego, CA, USA 
compounds and chemically modifying the substrate. Cellulose oxidation potentially interferes with enzyme binding and/or active site interaction.

Alexander Varvak from Verenium Corporation described efforts to develop de novo enzyme cocktails optimized for specific biomass feedstocks and pretreatment conditions. In addition, he described Verenium's DirectEvolution ${ }^{\mathrm{TM}}$ technologies and high-throughput screening methods and presented an example of using this technology to improve the thermostability of a GH11 xylanase by $25{ }^{\circ} \mathrm{C}$.

Matti Siika-aho from VTT Technical Research Centre of Finland compared the performance of thermostable fungal Cel7A enzymes to the Cel7A of T. reesei. Pretreated raw materials were efficiently hydrolyzed at elevated temperatures by the thermostable enzymes. In addition, he shared work on "domain swapping" experiments in which the catalytic and carbohydrate binding domains from thermophilic and mesophilic proteins were mixed and matched and then performance-assessed on soluble and insoluble substrates.

Antoine Margeot from the France Petroleum Institute presented very detailed secretome maps of two T. reesei strains (RutC30 and CL847) grown on different substrates and inducers that revealed information on regulation of cellulases and hemicellulases. Miniaturized hydrolysis assays with purified enzymes allowed reconstitution of the enzymatic pools and clarification of the role of each enzyme in the substrate degradation. 